\title{
A STUDY OF THE ECOLOGICAL REQUIREMENTS OF WATERFOWL AT MAN-MADE RESERVOIRS IN KHEDA DISTRICT, GUJARAT, INDIA, WITH A VIEW TOWARDS CONSERVATION, MANAGEMENT AND PLANNING
}

\author{
Aeshita Mukherjee ${ }^{1}$, C.K. Borad ${ }^{2}$ and B.M. Parasharya ${ }^{3}$ \\ 1,2 Gujarat Institute of Development Research, Gota, Ahmedabad, Gujarat 382481, India. \\ ${ }^{3}$ All India Network Project on Agricultural Ornithology, Gujarat Agricultural University, Anand, Gujarat 388110, India. \\ IEmail:aeshitam@yahoo.com
}

\begin{abstract}
The population of waterfowl in the reservoirs of Kheda District, Gujarat, India was studied from 1988 to 2000. Observations were made in January each year at three study sites where the waterfowl population was the highest. Factors contributing to the presence of the waterfowl in these three reservoirs included abundant food supply and safe roosting sites. Coots were the most abundant of the 112 species observed. Habitat size and complexities were important factors influencing the species diversity of the particular site. Sarus Crane was the nesting species in this area. The nesting success of the Sarus Crane was influenced by protection of the nesting sites by farmers. Both site-specific and broad-based strategies are suggested for future management.
\end{abstract}

Keywords

Urban wildlife, waterfowl, habitat, diversity, coots, comb ducks, important bird area, reservoirs, Sarus Crane, nesting sites

\section{Introduction}

The need to maintain and enhance the urban and suburban populations of wildlife has greatly increased in recent past, due to a desire to observe wildlife closer to home and a concern to protect the habitat from rapid urbanization (Shomon et al., 1974; Hoover 1976). Barens (1966), Dagg (1970) and Washington (1978) have emphasized the need to foster wildlife awareness among urban dwellers so that the policies made for wildlife and protection issues can be better evaluated.

Planners who take environmental decisions on limited information available on biological components of the area to be impacted also become misleading (Meyer, 1979). Therefore, we strongly feel that habitat requirements of individual species must be known before the implementation of management or planning schemes. Many studies have discussed the necessity for information about the habitat components that are important in the urban areas (DeGraaf \& Thomas, 1974; DeGraaf, 1978; Greer, 1983). Geis (1980) stated there is a need "... for more research on wildlife in urban areas to obtain detailed knowledge on the characteristics of urban fish and wildlife populations". His statement further emphasizes the need for publications dealing with urban wildlife and their habitat management potentials.

Planning for wildlife in urban areas is often stiffled by inadequate support and collaboration from resource agencies and lack of awareness and expertise in wildlife matters by urban planners (Davey, 1967; Strange, 1967; Twiss, 1967; Tubbs \& Blackwood, 1971; Leedy et al., 1978; Geis, 1980). City planners have ultimate responsibilities for incorporating wildlife issues into the planning process, and the results have not being encouraging (Shafer \& Moeller, 1974; Gray et al., 1979).

The solution to this dilemma is either to encourage greater collaboration between wildlife regulatory agencies and municipal planners (Greer, 1983) or to familiarize the planners with wildlife resources through literature relevant to both the disciplines. This study addresses the latter option by discussing the habitat 


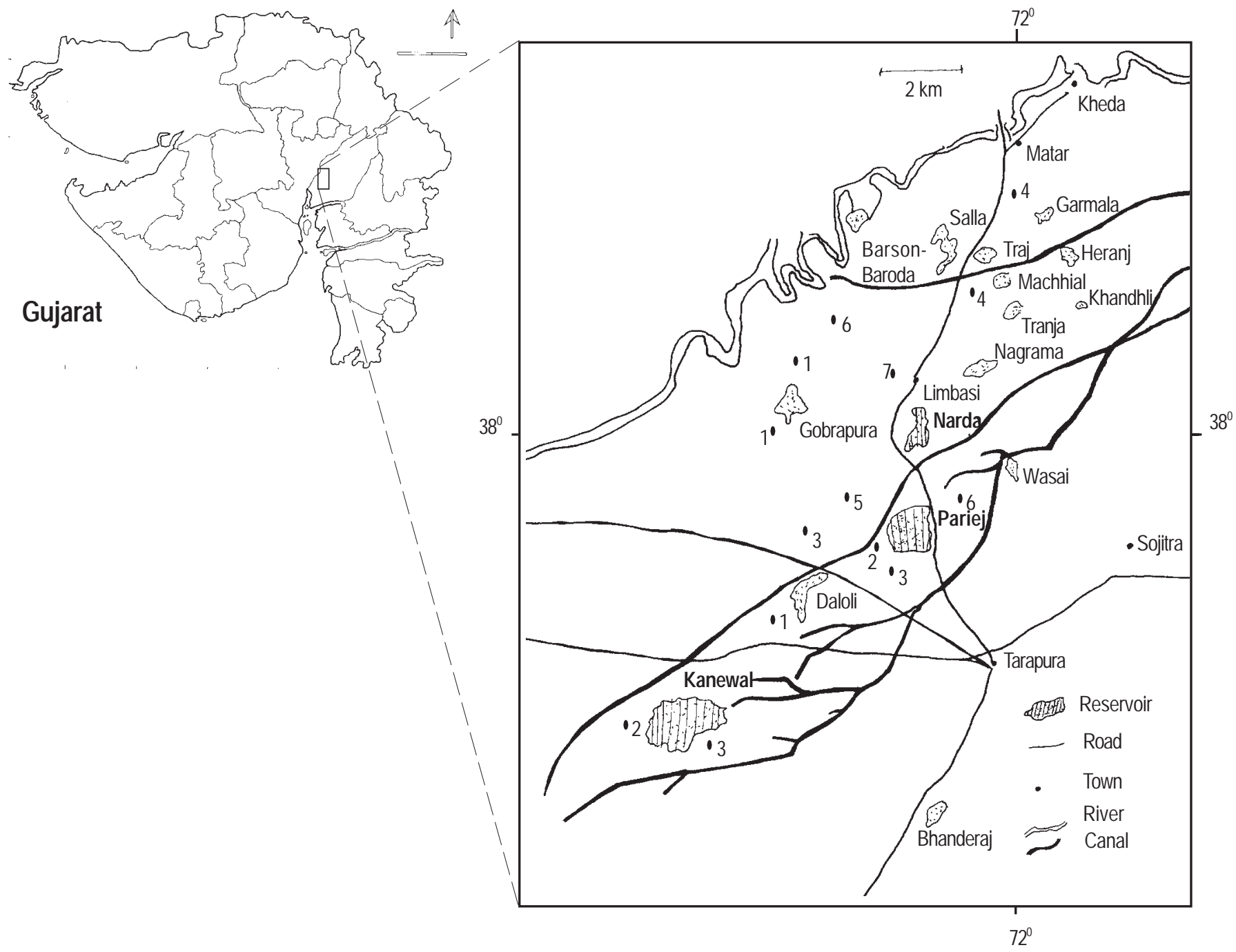

Figure 1. Map showing the location of canal linked reservoirs (in bold) and number of Sarus Crane nests located in the study area

requirement of waterfowl population in reservoirs of Kheda District, Gujarat. We also attempt to identify factors that contribute to the attraction of waterfowl to these reservoirs and suggest management and planning strategies for maintaining waterfowl in urban environments.

\section{Study area}

The study area encompasses the three major canal-linked reservoirs of Kheda District, Gujarat (Fig. 1). All the three reservoirs are fed through canals as per irrigation demands from the farmers. The whole study area is $526 \mathrm{~km}^{2}$.

Narda is a 57ha storage reservoir fed by canals and was designed for irrigation purposes; discharges averages 65cf (State Irrigation Department, Gujarat). The water quality is good, but by the onset of summer it becomes shallow and with abundant aquatic vegetation. Narda is also used for fishing. The surrounding area is agricultural landscape and the main crop is paddy, Oryza sativa.

Pariej is the second largest (445ha) water storage reservoir of the district. It was built to fulfill the drinking water requirement of the surrounding 52 villages, and therefore the wetland is perennial. The water depth fluctuates from $3-4 \mathrm{~m}$. The landscape around Pariej is mostly saline and as a result no crops are grown. Due to water seepage from the reservoir, the whole area is waterlogged and acts as a permanent marsh with heavy growth of reeds (Typha angustata) and other aquatic vegetation. Commercial fishing is also practiced in this reservoir. 
Kanewal is the largest reservoir in the district (625ha). The land surrounding the reservoir is salt affected and remains dry during summer. During monsoon it becomes innundated with water, a temporary refuge for migratory waterfowl. Kanewal provides drinking water to 57 villages. During summer the reservoir reaches the dead storage level (almost no water) and only the wet bed is seen.

\section{Methods}

\section{Survey}

Waterfowl counts were made on every second week of January from 1988 to 2000 at Narda, Pariej and Kanewal reservoirs (Fig. 1) thus making one survey each year. We chose sites with highest concentration of waterfowl and easy approachability during dawn. As waterfowls in these reservoirs concentrate in large numbers, total waterfowl counts were conducted at different locations.

Plant composition and cover of the herbs and shrub for the entire study area was also recorded. Bank vegetation along the reservoirs was examined with $1 \mathrm{~m}^{2}$ quadrats (based on transect belt of $100 \mathrm{~m}$ from edge of the reservoir) placed at $50 \mathrm{~m}$ intervals along parallel transects at five points. This was done to see the impact of these vegetation on presence of birds. Plant percentage cover was assigned to individual plant species according to Phillips (1959) and were as follows: <1\%, 1- 10\%, $10-25 \%, \ldots . .75-100 \%$. Values of relative dominance and relative frequency were summed to provide the importance values for individual plant species. Importance values of plants located are listed in Table 1.

Nests of Sarus Cranes were located by walking the entire study area every week from June 1999 to September 1999. Nests were marked using plastic flags with nest number. At each nest site, the plant cover and the height of vegetation was determined. Nests were monitored until the fledging stage.

\section{Analysis}

The Shannon-Weiner index (Shannon \& Weiner, 1963) was used to calculate the species diversity of the waterfowl population:

$$
\mathrm{H}^{\prime}=-\Sigma p_{i} \ln p_{i}
$$

Where $\mathrm{H}^{\prime}$ is the species diversity index and $p_{i}$ is the proportion of the total number of individuals belonging to the $i^{\text {th }}$ species. This index was further divided into species richness $(s=$ number of species) and equitability $\left(\mathrm{J}^{\prime}=\mathrm{H} / \mathrm{H}^{\prime} \max \right)$ where H'max is the natural logarithm of the total number of species.

Difference of measured variables between the three locations were analysed using analysis of variance (ANOVA). Means of significant relationship were separated using Duncan's New Multiple Range Test (DNMRT). All diversity values were square root transformed $\left(x^{\prime}=V x+1\right.$, Snedecor $\&$ Cochran, 1967) prior to analysis.

The degree of tolerance and importance values were calculated and assigned following the methodology shown by Greer (1983).

\section{Results}

\section{Vegetation}

Amongst the vegetation, paddy (Oryza sativa) and wheat (Triticum aestivum) were the cultivated crops in the study area. Undisturbed vegetation was largely found on the banks of the water bodies. The plant composition was evaluated for the entire study area (Table 1).

Narda was surrounded by small aquatic vegetation (19 spp.) but

Table 1. Importance values of plants located along the banks of the reservoirs.

\begin{tabular}{|c|c|c|c|}
\hline \multirow[t]{2}{*}{ Scientific name } & \multicolumn{3}{|c|}{ Importance values } \\
\hline & Narda & Pariej & Kanewal \\
\hline Oryza sativa & 87.13 & 38.12 & 1.23 \\
\hline Echinocloa colonum & 42.23 & 31.33 & 13.25 \\
\hline Cynodon dactylon & 18.23 & 33.13 & 33.33 \\
\hline Ipomoea aquatica & 37.72 & 14.24 & 42.0 \\
\hline Ipomoea carnea & 4.72 & 7.13 & 15.3 \\
\hline Typha angustata & 3.99 & 48.12 & 65.3 \\
\hline Digitaria sanguinalis & 10.23 & 4.28 & 4.21 \\
\hline Cyperus rotundus & 3.22 & 78.23 & 4.42 \\
\hline Argemone mexicana & 4.73 & - & - \\
\hline Commelina benghaleni & 3.99 & 7.13 & 1.12 \\
\hline Kirganelia reticulata & 2.63 & - & 2.67 \\
\hline Eichhornia crassipes & 7.18 & 1.96 & - \\
\hline Scirpus littoralis & - & 19.21 & 5.67 \\
\hline Marcelia sp. & 1.23 & - & 28.25 \\
\hline Hydrilla verticillata & - & 1.21 & 1.22 \\
\hline Nymphoides indica & 2.23 & & 92.20 \\
\hline Najas graminea & 1.73 & 1.11 & - \\
\hline Paspalum distichum & 2.33 & - & \\
\hline Oryza rufipogon & 4.71 & - & 1.25 \\
\hline Limnophyton obtusifolium & 0.54 & 1.17 & - \\
\hline Eleochharis duleis & 0.70 & - & - \\
\hline Digitaria ciliaris & 0.66 & 0.23 & - \\
\hline
\end{tabular}


predominantly with Echinocloa colonum (Table 1). Acacia trees were patchily distributed on the bank of the reservoir. Apart from weeds, paddy was extensively grown around the reservoir.

Pariej: Cyperus rotundus was the dominant species here. Typha angustata was the next dominant species. Echinocloa colonum, Cynodon dactylon and Ipomoea aquatica were also substantial. A total of 15 species of vegetation were found in the reservoir.

Kanewal: Najas gramina was the most important plant species in the reservoir. Other important species were Typha angustata, Ipomoea aquatica and Cynodon dactylon. The trees on the bank of the reservoir were Prosopis cineraria. A total of 14 species of vegetation were observed in this location.

\section{Relative abundance and diversity of waterfowls}

Observations at all the three reservoirs showed waterfowl initiated their diurnal activity in early morning $(30+5 \mathrm{~min})$ before sunrise. Most of the activities (foraging, preening, swimming and feeding) ceased within 15 minutes after initiation. The movements of these waterfowl was a function of feeding preference. The morning counts allowed for better incorporation of all the species utilizing the reservoirs due to limited human disturbances and interference. The checklist of waterfowl observed in these reservoir and their relative tolerance to human presence is shown in Table 2.

Narda: Wintering waterfowl population were attracted to the reservoir specially in the shallow area with aquatic grasses and by residential Cyperus sp.on the other side. During summer the reservoir was utilised mainly by the Indian Sarus Crane Grus antigone antigone and a few waders. Migratory waterfowl began arriving in October and the diversity increased significantly through the winter months (Fig. 2) and become maximum during January. The undisturbed portion of the reservoir was mainly Cyperus rotundus and Ipomoea aquatica on one side and the other side had Typha angustata. The whole bank had a growth of Acacia nilotica and Prosopis juliflora. Coots Fulica atra
Table 2. Waterfowl observed in the reservoirs and relative tolerance to human presence.

\begin{tabular}{|c|c|c|c|c|c|}
\hline \multirow[t]{2}{*}{ Common name } & \multirow[t]{2}{*}{ Scientific name } & \multicolumn{4}{|c|}{ Degree of tolerence } \\
\hline & & $\mathrm{H}$ & $\mathrm{M}$ & $\mathrm{S}$ & No \\
\hline \multicolumn{6}{|l|}{ Grebes } \\
\hline Little Grebe & Tachybaptus ruficollis & - & * & - & - \\
\hline Black-necked Grebe & Podiceps nigricollis & - & - & * & - \\
\hline Great Crested Grebe & Podiceps cristatus & - & - & * & - \\
\hline \multicolumn{6}{|l|}{ Pelicans } \\
\hline Great White Pelican & Pelecanus onocrotalus & - & * & - & - \\
\hline Dalmatian Pelican & Pelecanus crispus & - & * & - & - \\
\hline \multicolumn{6}{|l|}{ Cormorants } \\
\hline Indian Shag & Phalacrocorax fuscicollis & * & - & - & - \\
\hline Little Cormorant & Phalacrocorax niger & * & - & - & - \\
\hline Great Cormorant & Phalacrocorax carbo & * & - & - & - \\
\hline \multicolumn{6}{|l|}{ Darters } \\
\hline Darter & Anhinga melanogaster & * & - & - & - \\
\hline \multicolumn{6}{|c|}{ Herons, Egrets and Bitterns } \\
\hline Yellow Bittern & Ixobrychus sinensis & - & - & - & * \\
\hline Chestnut Bittern & Ixobrychus cinnamomeus & - & - & - & * \\
\hline Black Bittern & Ixobrychus flavicollis & - & - & - & * \\
\hline Black-crowned Night H & ron Nycticorax nycticorax & - & * & - & - \\
\hline Indian Pond-heron & Ardeola grayii & * & - & - & - \\
\hline Cattle Egret & Bubulcus ibis & * & - & - & - \\
\hline Western Reef Egret & Egretta gularis & - & * & - & - \\
\hline Little Egret & Egretta garzetta & - & * & - & - \\
\hline Median Egret & Mesophoyx intermedia & - & * & - & - \\
\hline Great Egret & Egretta alba & - & * & - & - \\
\hline Purple Heron & Ardea purpurea & - & - & * & - \\
\hline Grey Heron & Ardea cinerea & - & - & * & - \\
\hline \multicolumn{6}{|l|}{ Storks } \\
\hline Painted Stork & Mycteria leucocephala & - & * & - & - \\
\hline Asian Openbill-Stork & Anastomus oscitans & * & - & - & - \\
\hline White-necked Stork & Ciconia episcopus & - & - & * & - \\
\hline Europran White Stork & Ciconia ciconia & - & - & * & - \\
\hline Black-necked Stork & Ephippiorhynchus asiaticus & - & - & * & \\
\hline
\end{tabular}

Ibis and Spoonbills were the most abundant species except in 1989 when water was the limiting factor and as a result the waders were abundant.

Among ducks, Gadwal (Anas strepera) and Spot-billed Duck (Anas poecilorhyncha) were predominant. Mallards (Anas platyrhynchos) were seen during 1988 (57), 1994 (10) and 1996 (49). Ferruginous Ducks (Anas nyroca) were only seen once during 1988 (2). Most of the ducks were found foraging in the crop fields especially the Combducks (Sarkidiornis melanotos) and Cotton Teals (Nettapus coromandelianus). The significant difference in duck number wSas observed during the study period $(\mathrm{P}=0.001$, Table 3$)$ could be attributed to the Combduck population. The waterfowls preferred the crop fields because of the availability of food (grass tubers, shattered grains, small molluscs) and almost fixed water depth $(<1 \mathrm{~m})$.

Oriental White lbis

Black Ibis

Glossy lbis

Eurasian Spoonbill

Flamingoes

Greater Flamingo

Lesser Flamingo

Geese and Ducks

Lesser Whistling Duck

Greylag Goose

Brahminy Shelduck

Common Shelduck

Comb Duck

Indian Cotton Teal

Threskiornis
melanocephalus
Pseudibis papillosa
Plegadis falcinellus
Platalea leucorodia
Phoenicopterus ruber
Phoenicopterus minor

Denarocygna javanica
Anser anser
Todorna ferruginea
Todorna tadorna
Sarkidiornis melanotos
Nettapus

Threskiornis

Pseudibis papillos

Plegadis falcinellus

Platalea leucorodia

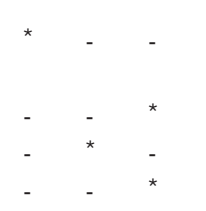




\begin{tabular}{|c|c|c|c|c|c|c|c|c|c|c|c|}
\hline \multirow[t]{2}{*}{ Common name } & \multirow[t]{2}{*}{ Scientific name } & \multicolumn{4}{|c|}{ Degree of tolerence } & \multirow[t]{2}{*}{ Common name } & \multirow[t]{2}{*}{ Scientific name } & \multicolumn{4}{|c|}{ Degree of tolerence } \\
\hline & & H & $M$ & $\mathrm{~S}$ & No & & & $\mathrm{H}$ & $M$ & $\mathrm{~S}$ & No \\
\hline & coromandelianus & & & & & Common Greenshank & Tringa nebularia & - & - & - & * \\
\hline Eurasian Wigeon & Anas penelope & - & - & * & - & Green Sandpiper & Tringa ochropus & - & - & * & - \\
\hline Gadwall & Anas strepera & - & - & * & - & Wood Sandpiper & Tringa glareola & - & - & - & * \\
\hline Mallard & Anas platyrhynchos & * & - & - & - & Terek Sandpipper & Xenus cinereus & - & - & - & * \\
\hline Common Teal & Anas crecca & - & - & * & - & Common Sandpiper & Actitis hypoleucos & - & - & - & * \\
\hline Spot-billed Duck & Anas poecilorhyncha & - & - & * & - & Common Snipe & Gallinago gallinago & - & - & - & * \\
\hline Northern Pintail & Anas acuta & - & - & * & - & Little Stint & Calidris minuta & - & - & - & * \\
\hline Garganey & Anas querquedula & - & - & * & - & Temminck's Stint & Calidris temminckii & - & - & - & * \\
\hline Northern Shoveler & Anas clypeata & - & - & - & * & Dunlin & Calidris alpina & - & - & - & * \\
\hline Red-crested pochard & Rhodonessa rufina & - & - & - & * & Curlew Sandpiper & Calidris ferruginea & - & - & - & * \\
\hline Common Pochard & Aythya ferina & - & - & - & * & Sanderling & Calidris alba & - & - & - & * \\
\hline Tufted Pochard & Aythya fuligula & - & - & - & * & Ruff & Philomachus pugnax & - & - & - & * \\
\hline Ferruginous Pochard & Aythya nyroca & - & - & - & * & Gulls, Terns and Skimmers & & & & & \\
\hline Cranes & & & & & & Herring Gull & Larus agentatus & - & - & * & - \\
\hline Sarus Crane & Grus antigone antigone & * & - & - & - & Lesser Black-backed Gull & Larus fuscus & - & - & * & - \\
\hline Common Crane & Grus grus & - & * & - & - & Pallas Gull & Larus icthyaetus & - & - & * & - \\
\hline Demoiselle Crane & Grus virgo & - & * & - & - & Brown-headed Gull & Larus brunnicephalus & - & - & * & - \\
\hline & & & & & & Black-headed Gull & Larus ridibundus & - & - & * & - \\
\hline Rails, Gallinules and Coots & & & & & & Slender-billed Gull & Larus genei & - & * & - & - \\
\hline Water Rail & Rallus aquaticus & - & - & - & * & Whiskered Tern & Chlidonias hybridus & - & - & - & * \\
\hline Brown Crake & Amaurornis akool & - & - & - & * & White-winged Black Tern & Chlidonias leucopterus & - & - & - & * \\
\hline White-breasted Waterhen & Amaurornis phoenicurus & - & - & - & * & Gull-billed Tern & Gelochelidon nilotica & - & - & * & - \\
\hline Water Cock & Gallicrex cinerea & - & * & - & - & & $\begin{array}{l}\text { Gelocnelldon nilodica } \\
\text { Sterna caspia }\end{array}$ & ${ }^{-}$ & - & $\hat{x}$ & * \\
\hline Common Moorhen & Gallinula chloropus & - & - & - & * & Caspian lern & & - & - & - & ${ }^{*}$ \\
\hline Purple Moorhen & Porphyrio Porphyrio & - & - & - & * & River Tern & Sterna aurantia & - & - & - & * \\
\hline Common Coot & Fulica atra & - & - & * & - & Common Tern & Sterna hirundo & - & - & - & $*$ \\
\hline Jacanas & & & & & & Little Tern & Sterna albifrons & - & - & - & * \\
\hline Pheasant-tailed Jacana & Hydrophasianus chirurgus & - & * & - & - & Skimmers & & & & & \\
\hline Bronze-winged Jacana & Metopidius indicus & - & * & - & - & Indian Skimmer & Rynchops albicollis & - & - & * & - \\
\hline Shorebirds - Waders & & & & & & Total & & 12 & 21 & 28 & 51 \\
\hline
\end{tabular}

Painted Snipe

Oystercatcher

Crab-Plover

Black-winged Stilt

Pied Avocet

Great Stone-Plover

Small Pratincole

Small Collard Pratincole

Yellow-wattled Lapwing

Sociable Lapwing

White-tailed Lapwing

Red-wattled Lapwing

Pacific Golden-Plover

Grey Plover

Little Ringed Plover

Kentish Plover

Greater Sand Plover

Black-tailed Godwit

Bar-tailed Godwit

Whimbrel

Eurasian Curlew

Spotted Redshank

Common Redshank

Marsh Sandpiper
Rostratula benghalensis Haematopus ostralegus Dromas ardeola Himantopus himantopus Recurvirostra avosetta

Esacus recurvirostris

Glareola lactea

Glareola pratincola

vanellus malabaricus

Vanellus gregarius

Vanellus leucurus

Vanellus indicus

Pluvialis fulva

Pluvialis squatarola

Charadrius dubius

Charadrius alexandrinus

Charadrius leschenaultii

Limosa limosa

Limosa lapponica

Numenius pheopus

Numenius arquata

Tringa erythropus

Tringa totanus

Tringa stagnatilis
The diversity index is influenced by the interaction of species richness (s) and equatibility (J') (Kricher, 1972). The interaction of these factor is evident in Narda Reservoir (Fig. 2). Increasing or decreasing the evenness with which the species were numerically distributed (J') always solicited a corresponding reaction from the diversity index.

Pariej: Pariej has comparatively higher seasonal diversity than Kanewal and Narda (Fig. 3). Vegetation on the bank of the reservoir was generally an undisturbed mixture of reeds and aquatic grass. Dalmatian Pelicans (Pelecanus crispus) were especially attracted to this location due to the presence of fish fauna. Coots dominated the species year-round. Gadwall (Anas strepera), Northern Shoveller (Anas clypeata), Northern Pintail (Anas acuta), Eurasian Wigeon (Anas penelope) were also predominant species of the reservoir and were regularly observed. Average number of ducks/ha ranged from 0.26-8.98 and was significant $(\mathrm{P}=0.001)$ compared to other two reservoirs. Mallard (Anas platyrhyncos) (11) were observed only once in 1990 . The 


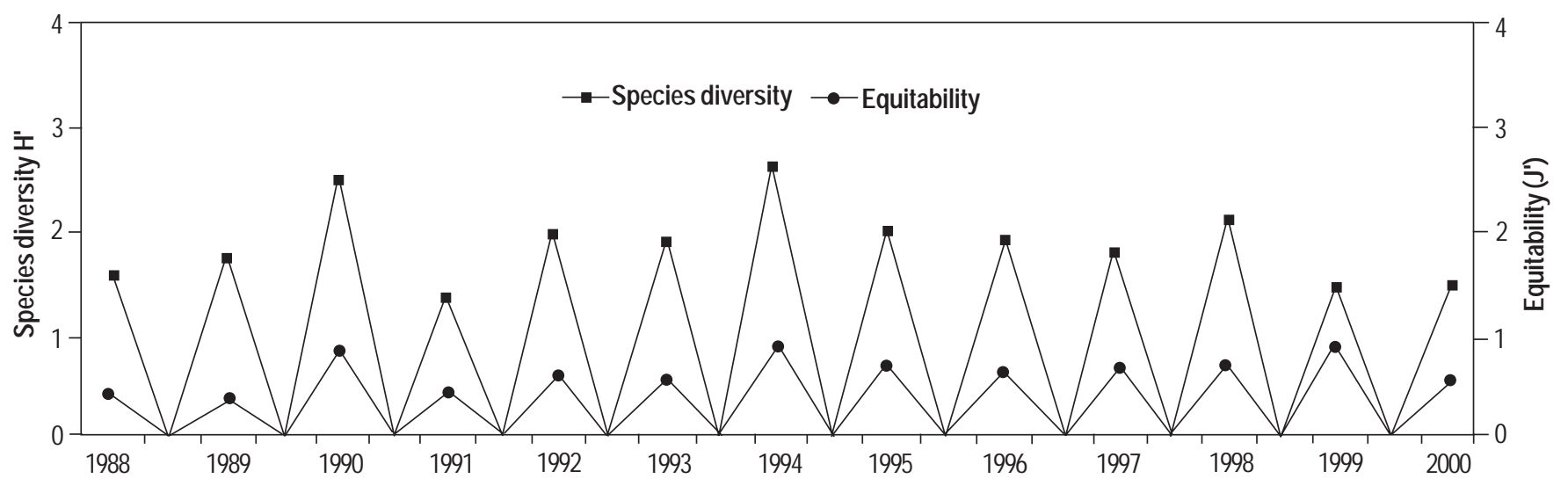

Narda
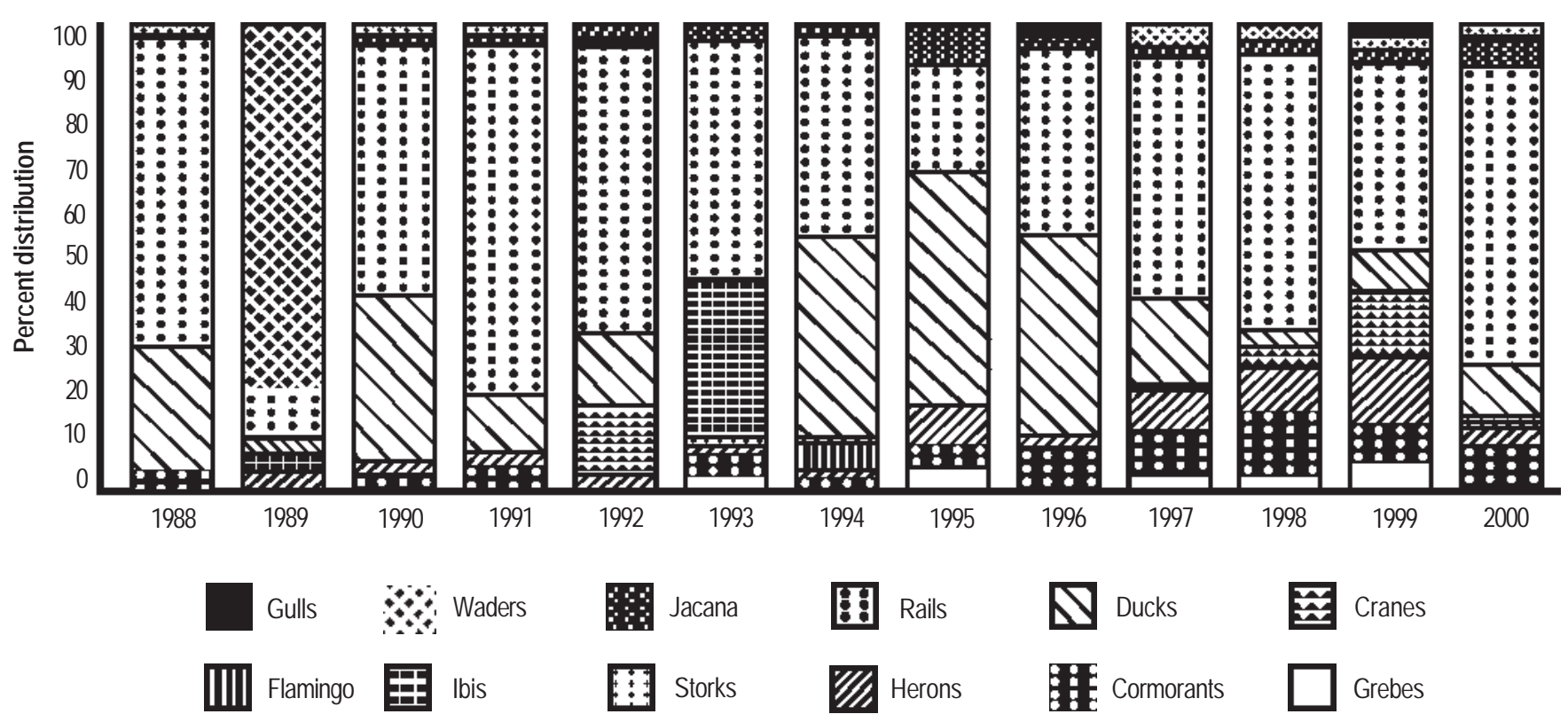

Figure 2. Relationship of species richness and species equitability $\left(\mathrm{J}^{\prime}\right)$ of Narda waterfowls to the diversity index $\left(\mathrm{H}^{\prime}\right)$, and percent distribution of categorised group of waterfowls during the study period

reservoir also attracts Dalmatian Pelican and Black-necked Grebe (Podiceps nigricollis). It is a potential nesting site for the Greatcrested Grebe (Podiceps cristatus) too. A combination of both equal distribution of $\left(\mathrm{J}^{\prime}\right)$ and high species richness (s) was responsible for the high diversity at this site.

Kanewal: Short grasses and emergent vegetation within the reservoir was the main attraction for the migratory waterfowl in this reservoir. Ducks congregated at the reservoir basically feed on the small invertebrates and tubers of aquatic weeds (Najas gramina). Species richness was highest at this site as it is the only water body in the area, shallow and with high food availability. Diversity had increased due to the increase in individuals within the species (J') (Fig. 4). Significantly, more ducks 1.04-6.95 ( $\mathrm{P}<0.0001)$ visited the reservoir (Table 3).

Dalmatian Pelican, Red-crested Pochards (Rhodonessa rufina) and Demoiselle Cranes (Grus virgo) are the attraction of this reservoir. We never observed Mallards in this reservoir probably the species such as Mallards have a tendency to feed in the open agricultural area which is absent around Kanewal. Species of diving ducks always remained in the reservoir.

Site interrelationships: Each site differed with respect to size and habitat complexity. Coots found in large numbers in all the three reservoir shows the commoness in the physical features 


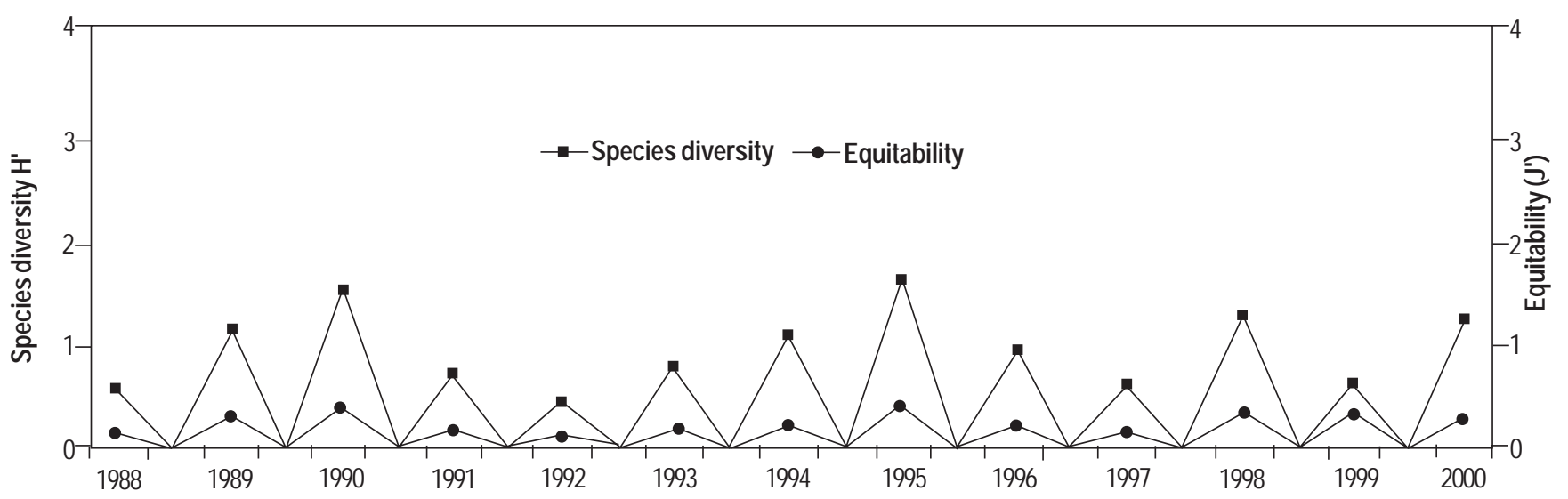

Pariej

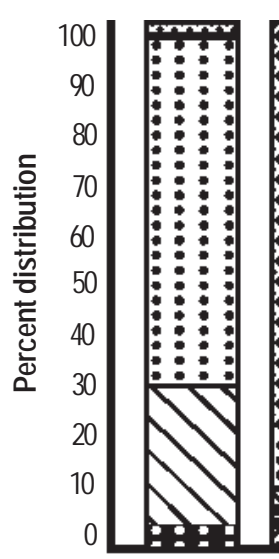

1988

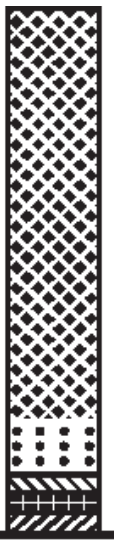

1989

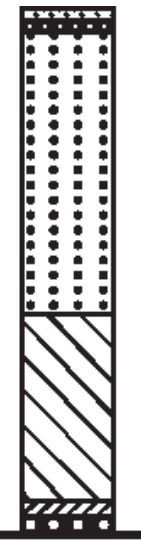

1990

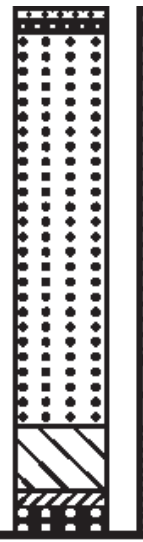

1991

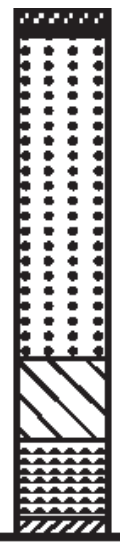

1992

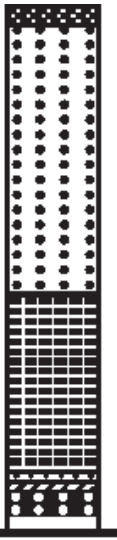

1993

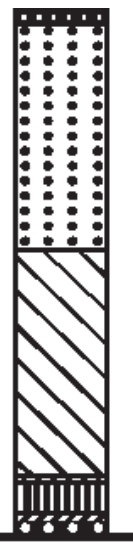

1994

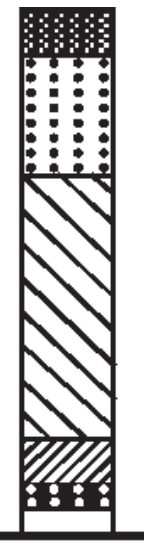

1995

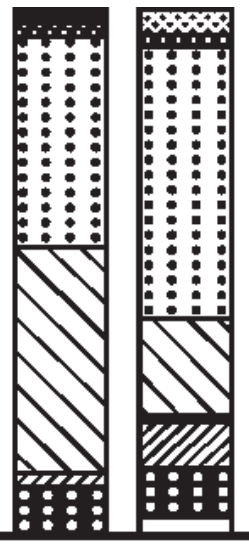

1996

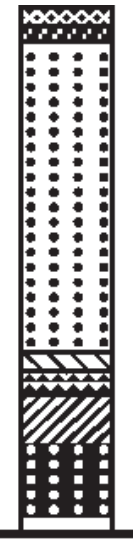

1997

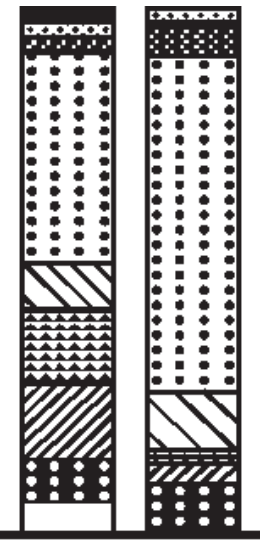

$1998 \quad 1999 \quad 2000$

Ducks

Cranes

III Flamingo 포 Ibis

Storks

E3 Rails

Cormorants

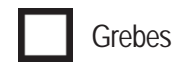

Figure 3. Relationship of species richness and species equitability ( $\left.\mathrm{J}^{\prime}\right)$ of Pariej waterfowls to the diversity index ( $\left.\mathrm{H}^{\prime}\right)$, and percent distribution of categorised group of waterfowls during the study period

of the reservoir. However, the ducks preferred somewhat shallow area of the reservoir. Narda was most preferred by the ducks and waders. All the reservoirs become the sole source of stay for the cranes during summer.

Figure 5 shows the effect of increased sampling area on the diversity index. The study site was grouped to include more habitat types and create a large sampling unit. The result suggests that the overall waterfowl diversity of Pariej was comparable to Kanewal. This interrelationship suggests that for feeding, several distinct locations with difference in habitat qualities are necessary, while it also predicts that the same habitat is not suitable for other activities like resting or loafing. The result also indicated that these reservoirs are not totally dependent on each other but they act as independent microhabitat in sustenance of migratory waterfowls.

\section{Nesting waterfowl}

The Sarus Crane nesting could be studied in this area during monsoon months. Reproductive behaviour intensified by May and June and copulation attempts were frequent, and, successful mating took place by the end of June to first week of July (Borad et al., 1999).

\section{Nest-site selection}

Egg laying began on 26 June and peaked by the first week of 


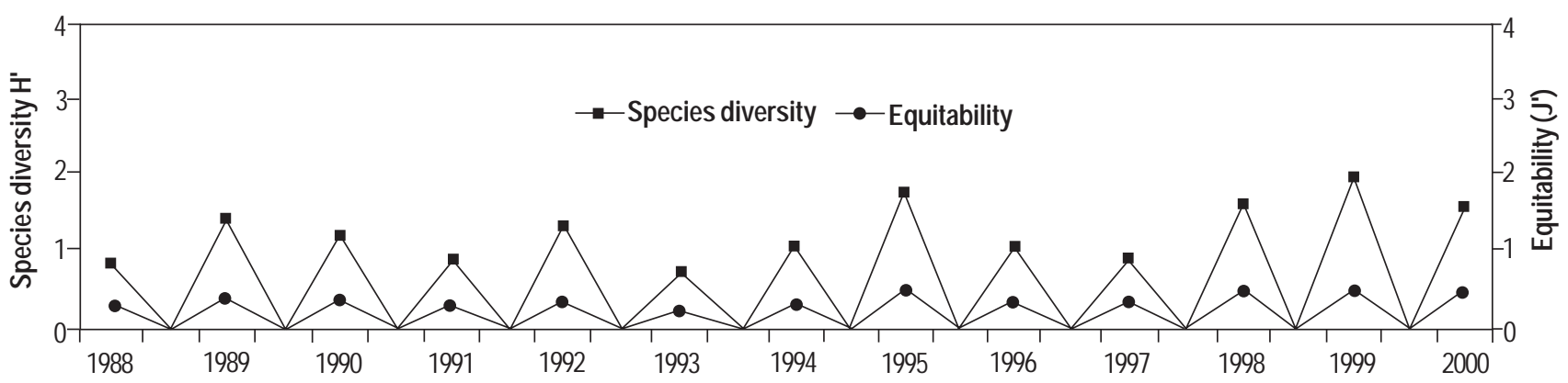

Kanewal

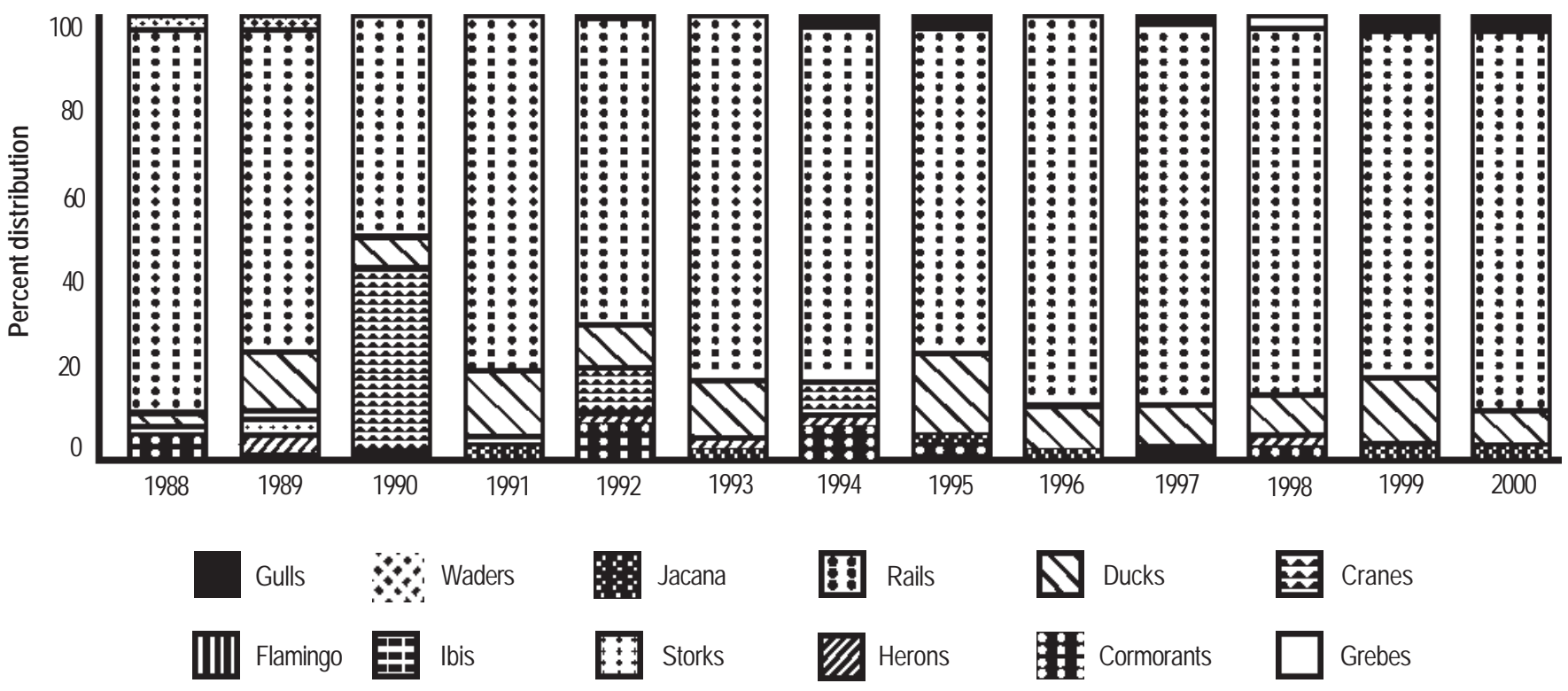

Figure 4. Relationship of species richness and species equitability (J') of Kanewal waterfowls to the diversity index ( $\left.\mathrm{H}^{\prime}\right)$, and percent distribution of categorised group of waterfowls during the study period

Table 3. Difference in measured variables between 1988-2000 winter for each reservoir site.

\begin{tabular}{|c|c|c|c|}
\hline Variables & $\begin{array}{l}\text { Study sites } \\
\text { Narda }\end{array}$ & Pariej & Kanewal \\
\hline Average No. of Ducks /ha & $0.21-15.42^{a}$ & $0.26-8.98^{a}$ & $1.04-6.95^{a}$ \\
\hline Average No. of other species/ha & $1.68-78.21^{a}$ & $9.59-59.13^{a}$ & a $19.68-63.97^{a}$ \\
\hline Average No. of species & $12-36^{c}$ & $36-85^{a}$ & $26-65^{b}$ \\
\hline $\mathrm{H}^{\prime}$ & $1.27-2.76$ & $0.80-1.91$ & $0.4-1.64$ \\
\hline $\mathrm{J}^{\prime}$ & $0.34-8.7$ & $0.22-0.45$ & $0.11-0.41$ \\
\hline
\end{tabular}

a Significant at $p=0.0001$

${ }^{b}$ Significant at $p=0.01$

c Significant at $p=0.001$ by DNMRT

NB: (The values in the table are the range lowest - highest)

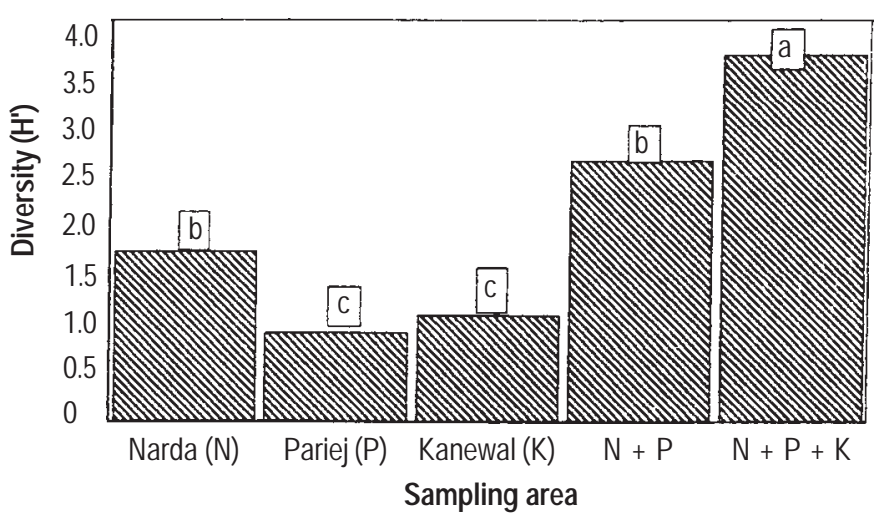

Figure 5. Effect of increased sampling area and the diversity index. Means between groups not accompanied with same letter are significantly different $(p=0.05)$ by DNMRT. 


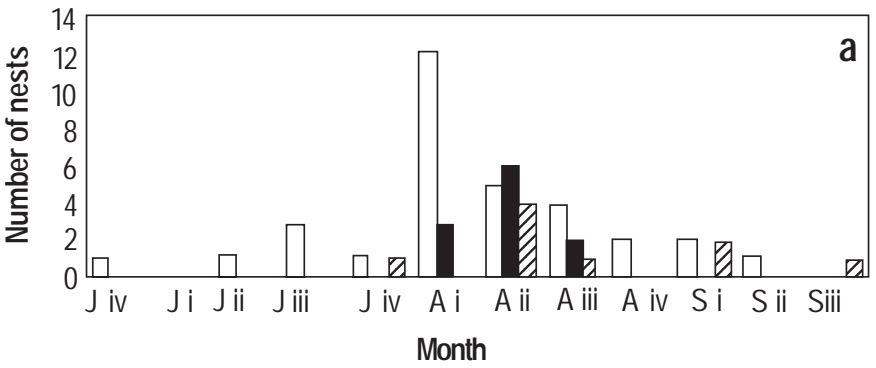

$\square$ Narda; $\square$ Pariej; $\square$ Kanewal

J i - June i; J i-iv - July i-iv; A i-iv - August i-iv; S i-iv - September i-iv Note: The nest initiation takes place from the fourth week of June (J iv) and continues up to the third week of September (S iii).

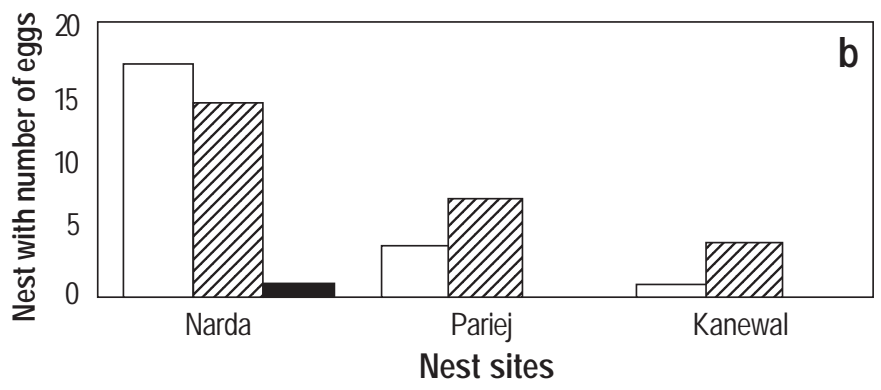

$\square$ one egg; $\square$ two eggs; $\square$ three eggs

Figure 6. Sarus Crane (a) Nest initiation and (b) eggs per nest in the study areas

August in Narda and surrounding area and by the second week around Pariej and Kanewal (Fig. 6a). All the nests were grouped in three locations - 32, 11 and five in and around Narda, Pariej and Kanewal, respectively. Table 4 summarizes the difference of measured variables between the three areas. Nest-site selection reflected the choice of tall $(<2 \mathrm{~m})$ and undisturbed vegetation.
Table 4. Differences in the nesting variables between the three locations.

\begin{tabular}{llll}
\hline \multirow{2}{*}{ Nesting area surrounding } & \multicolumn{3}{c}{ Nest site measurements } \\
& Narda & Pariej & Kanewal \\
\hline No. of nests (eggs) & $32(48)$ & $11(18)$ & $5(9)$ \\
Distance from water (m) & $10-15$ & 7 & 11 \\
Inter-nest distance (m) & 20 & 125 & 160 \\
Av. no. of eggs/nest & 1.5 & 1.63 & 0.9 \\
Av. no. of hatching/nest & 1.4 & 1.63 & 1.4 \\
Av. no. of fledgling/nest & 1.25 & 0.9 & 0.8 \\
\hline
\end{tabular}

Overall success $72 \%$

This a recognized factor for the Sarus Crane (Borad et al., 1999; Mukherjee, 1999). Predominant plant species at the nest and nest-site is shown in Table 5. Because of early nest initiation, Sarus Crane relied heavily upon stands of residual vegetation.

Vegetation recorded in the surrounding area of the reservoirs can be grouped into five plant assemblages (Fig. 7). Aquatic weeds and short vegetation were not suitable for nesting. Discriminate analysis based on plant cover and height indicated $59 \%$ of the area suitable for nesting. Plant community of the nest site (Table 5) closely reflected the vegetation composition of that area (Table 1). Nests were typically constructed either on the field bunds or within the fields and typha supported vertically in marsh.

Availability of nesting material and water depth around the nest were the controlling factors governing the nest-site selection. Usually the Cranes selected the agricultural area / marshland where the water fluctuation was minimum. Only one nest was recorded on the edge of the reservoir. The main drawback of

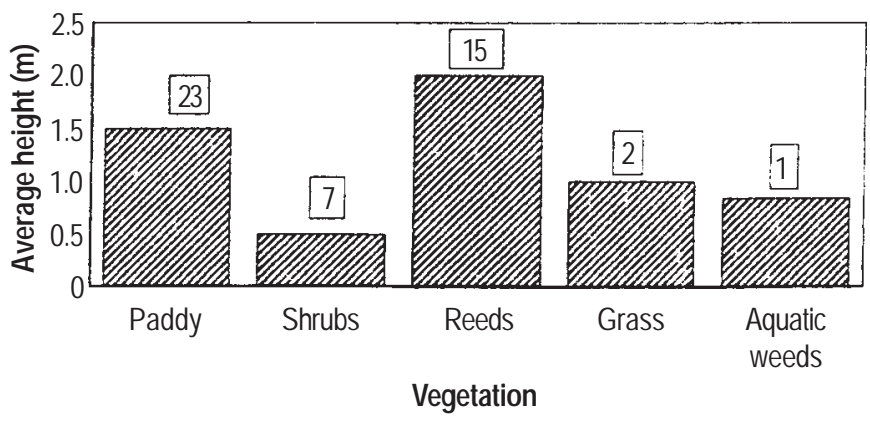

Figure 7. Nests of Sarus Crane found in different vegetation cover
Table 5. Predominant vegetation (\% Fi) used as nesting material at nest-site locations.

\begin{tabular}{llll}
\hline & \multicolumn{3}{c}{ Nest site surrounding } \\
Vegetation & Narda & Pariej & Kanewal \\
\hline Oryza sativa & 52.17 & 21.43 & - \\
Cynodon dactylon & 60.86 & 32.5 & - \\
Ipomea aquatica & 34.78 & 7.13 & 43 \\
Najas graminea & - & - & 89.96 \\
Typha angustata & - & 37.5 & 42.86 \\
Cyperus rotundus & - & 76.24 & 4.35 \\
\hline
\end{tabular}


reservoir was the high rate of water fluctuation. Of the 48 nests, 37 were placed at high levels on the bunds of the field. Sufficient nesting cover remained along the nest site. Nest location was also the source of readily available food.

Nest-sites were always close to the water. At Narda, nests averaged $10-15 \mathrm{~m}$ from water, in Pariej $7 \mathrm{~m}$, and $11 \mathrm{~m}$ in case of Kanewal. The greatest difference of nest-site selection between the three areas was the inter-nest distance, which was $20 \mathrm{~m}$ for Narda to $160 \mathrm{~m}$ for Kanewal (Table 4).

\section{Nesting success}

Clutch size of Sarus Crane is generally two. However in one case we found three eggs. Of the 48 nests observed during 1999, 25 had two eggs, and 22 had one egg (Fig. 6b). The brood size of the successful nests averaged from 1.5-1.8 (Table 4). Of the 75 eggs examined 54 chicks reached the fledgling stage. Thus the overall breeding success was $72.0 \%$ (Table 4). But if we think mathematically there should be 96 eggs ( 2 each in 48 nests) and 54 attended the fledgling stage, so the breeding success becomes $56.25 \%$ only. The nests with only one egg may be due to the result of predation or any other unknown reason.

\section{Problems / threats}

A variety of factors contributed to the poor nesting and brood survival observed in the study area. The factors responsible for nest abandonment were human interference, conflict between farmers and cranes, and sudden flooding due to release of water into the canals. Egg and chick predation by dogs, jackals, jungle crow and owl (?) were also threats to the crane. During the study period one nest was drowned due to careless and untimely visit by an overenthusiastic wildlife photographer near the nest. Egg-stealing by poor villagers was another reason of egg loss. Although we do not know the impact of pesticides on eggs, atleast seven adults and three subadults died due to pesticide toxicity. Nine cranes were found electrocuted.

\section{Discussion}

Food availability and feeding activities were responsible for concentration of waterfowl at three distinct reservoirs. Coots, Combduck and Spot-billed Ducks were the most abundant ducks observed at these sites. The diet included invertebrates, small fishes, aquatic vegetation, tubers and weeds. Combducks, Spotbilled Ducks, and teals also visited agricultural areas. Species of diving ducks always remained in the reservoir.

The diversity of a site was influenced by the number of species and relative abundance of individuals within species. Food was also a governing factor influencing diversity. Kanewal had high species richness and a more even distribution of individuals within species. The complex habitat at Pariej and Kanewal was especially suitable for supplying the varied habitat needs of a large number of species. Pariej with four waterfowl sites, a single habitat complex to obtain diversity value comparable to Narda and Kanewal. As an overall analysis, the species diversity of the waterfowl population was suppressed due to the absence of large varied microhabitats. Coots benefited because of wide availability of plant matter. Nesting habitat was suitable to the Sarus Crane as it adapted the paddy cultivations and marshy areas. The ability of the urban habitats to support waterfowl population is also dependent on outside selection and on the linkages with the rural surroundings (Davis \& Glick, 1978).

The presence of most species was attributed to a complex of various habitat and abundant food supply. The corridor strategy to increase waterfowl population has been well established (Gill \& Bonnet, 1973; Simberolff \& Abele, 1976); enhancement or improvement of the urban habitat is also possible as suggested by Stearns (1967), Lucid (1974), Shomon et al. (1974) and Leedy et al. (1978). To improve nesting success the threats described should be minimised.

Management strategies should focus on the bank vegetation that supplies cover and food to the birds. Sarus Crane in this study nested in relatively undisturbed areas close to water. Fledglings escaped safely under the overhanging vegetation when frightened. Nesting success and brood rearing would be improved by allowing the natural buffer of vegetation to develop along the wetland margins.

The problem treated in the paper is largely to (1) familiarize land managers and planners with wildlife resources in this highly managed environment, (2) elucidate the habitat requirements of waterfowl populations using the reservoirs and adjacent areas, and (3) attempt to focus the factors influencing waterfowl attraction to these reservoirs and possible ways to manage them.

\section{Conclusion}

The aim of many of these strategies can be implemented by: 1. Maintaining the canal leading to the reservoirs and 2. Maintaining the food availability of the reservoir. Existing legislation should be truly enforced. This would ensure greater consideration of wildlife habitat in the decision making process involving development proposals in the Important Bird Areas (IBA).

The areas which are often water-logged and provide important feeding and nesting habitats for the waterfowls should also be considered as sites of importance. Although these strategies may be the outcome of this study, it is likely that many are applicable at a broader spectrum. We hope that this study in this paper will eliminate many of the uncertainties involved in the development of such environmental plans. 


\section{Acknowledgements}

We are thankful to Indian Council of Agricultural Research for providing us partial financial assistance. Appreciation is extended to the Indian Institute of Rural Management and Gujarat Agricultural University for helping us in performing statistical analyses. Authors are grateful for the cooperation extended by the farmers of Kheda District during the study and helping with the conservation of the Sarus Crane.

\section{References}

Barens, I.R. (1966). Amid brick and asphalt, pp 414-424. In: Stefferud, A. and A. Nelson (Editors). Birds in Our Lives. USDI, Fish and Wildlife Service, USPGO.

Borad, C.K., A. Mukherjee, B.M. Parasharya (In press). Breeding performance of the Indian Sarus Crane Grus antigone antigone in paddy crop agroecosystem during 1996. Forktail.

Dagg, A.I. (1970). Wildlife in urban areas. Natural Canada 97: 201212.

Davey, S.P. (1967). The role of wildlife in an urban environment. Transaction of North American Wildlife Natural Resources Conference 32: 50-60.

Davis, A.M. and T.F. Glick (1978). Urban ecosystem and island biogeography. Evironmental Conservation 5: 299-303.

DeGraaf, R.M. (1978). Avian communities and habitat association in cities and suburbs, pp 7-24. In: Kirkpatric, C.M. (Editor) Proceedings: Wildlife and People. Purdue Research Foundation, West Lafayette.

DeGraaf, R.M. and J.W. Thomas (1974). A strategy for wildlife research in urban areas, pp 53-56. In: Noyes J.H. and D.R. Progulske (Editors). A symposium on wildlife in urbanized environment. Planning and Resource Development. Ser. No. 28. Holdsworth Natural Resources Center, University of Massachussets, Amherst, MA.

Geis, A.D. (1980). Elements of an urban wildlife program. The Wildlifer. No. 180.

Gill, D. and P. Bonnet (1973). Nature in the urban landscape: A study of city ecosystems. York Press, Baltimore, MD.

Gray, G.G., J.S. Larson and D.A. Branhardt (1979). Urban conservation leadership and the wildlife resource. Urban Ecology 4: 110.

Greer, D.M. (1983). Urban waterfowl population: Ecological Evaluation of management and planning. Environmental Management 6: 217-229.

Hoover, R.L. (1976). Incorporating fish and wildlife values in land use planning. Transaction of North American Wildlife Natural Resources
Conference 41: 280-289.

Kricher, L.M. (1972). Bird species diversity: the effect of species richness and equitability on the diversity index. Ecology 53: 280-282. Leedy, D.L., R.M. Maestro and T.M. Franklin (1978). Planning for wildlife in cities and suburbs. American Society of Planning Officials, Chicago, IL, and U.S. Fish and Wildlife Service, Washington DC. FWX/ OBS- 77/ 66.

Lucid, G.J. (1974). Bird utilization habitat in residential area. Ph.D. Dissertation. Virginia Polytechnic Institute and State University, Blacksburg VA (Unpublished).

MacArthur, R.H. and E.O. Wilson (1967). The Theory of Island Biogeography. Princeton University Press, Princeton, NJ.

Meyer, P.A. (1979). Economic value and the lesser snow geese of Wrangell Island-a demonstration with respect to migratory birds. Paper presented at the Northwest Section of the Wildlife Society, Portland, OR.

Mukherjee, A. (1999). Ecology of the Indian Sarus Crane. Ph.D Dissertation. Saurashtra University, Gujarat (Unpublished).

Phillips, E.A. (1959). Methods of Vegetation Study. Henry Holt and Company, Inc., NY.

Shafer, E.L. and G.H. Moeller (1974). Wildlife priorities and benefits: Now, 2000 and beyond. Transaction of North American Wildlife Natural Resources Conference 39: 208-220.

Shannon, C. and W. Weiner (1963). A Mathematical Theory of Communication. University of Illinois Press, Chicago, 117 pp.

Shomon, J.J., B.L. Ashbaug and C.D. Tolman (1974). Wildlife Habitat Improvement - Guidelines on Habitat Management Measures. National Audubon Society, NY.

Simberolff, D.C. and L.G. Abele (1976). Island biogeography theory and conservation practice. Science 191: 285 -286.

Snedecor, G.W. and W.G. Cochran (1967). Statistical Methods. $6^{\text {th }}$ ed. Iowa State University Press, Ames.

Stearns, F.W. (1967). Wildlife habitat in urban and suburban environments. Transaction of North American Wildlife Natural Resources Conference 32: 61-69.

Strange, T.D. (1967). Land use planning and zoning in conservation. Transaction of North American Wildlife Natural Resources Conference 32: 80-88.

Tubbs, C.R. and J.W. Blackwood (1971). Ecological evaluation of land for planning purposes. Biological Conservation 3: 169-172.

Twiss, R.H. (1967). Wildlife in metropolitan landscape. Transaction of North American Wildlife Natural Resources Conference 32: 69-74.

Washington, T. (1978). Wildlife and urban connection. Colorado Outdoors 27: $38-42$. 